\title{
A Comparative Study Between Expectant Management and Active Interference in Term PROM
}

\author{
Biswas $\mathrm{B}^{1}$, Jahan $\mathrm{I}^{2}$, Joty $\mathrm{FS}^{3}$, Nandi $\mathrm{ER}^{4}$, Dewan $\mathrm{F}^{5}$
}

\begin{abstract}
Background: Premature rupture of membranes (PROM) at term is an obstetrics problem which seeks special attention. Objective: The purpose of this study was to find out the better management option of term PROM. Methodology: This cross-sectional prospective cohort study was carried out in the department of Shaheed Suhrawardy Medical College Hospital between July 2012 to June 2013. Pregnant women presented with term PROM without any contraindication of vaginal delivery were included in the study. One group of patients ware managed expectantly and in other group was induced actively to identify the better outcome. Results: Time interval and hospital stay is less in active interference but failure is more. Foetal and maternal outcome is better in expectant management. Conclusion: Expectant management is a better option in the management of term PROM regarding both maternal and neonatal outcome. [J Shaheed Suhrawardy Med Coll 2015;5(2): 66-68]
\end{abstract}

Keywords: PROM, Labour, Expectant management, Active Interference

Received: April 2013; Revised: June 2015; Accepted: October 2013

\section{Introduction}

Premature rupture of membranes (PROM) is defined as spontaneous rupture of the membrane any time beyond 28 weeks of pregnancy but before the onset of labour. The membrane may rupture at term i.e. after 37 completed weeks of gestation called term PROM or earlier when it is called preterm PROM $^{1}$. The overall incidence of PROM is 2-18 percent \& in 94 percent cases there occurs term $\mathrm{PROM}^{2}$.Epidemiological studies have identified several risk factors associated with PROM. Genital tract infection or colonization of various micro organisms, coitus, low socio-economic status, poor nutrition, anaemia, poor hygiene, stress, high parity, smoking and bleeding in pregnancy have all been linked to an increased chances of $\mathrm{PROM}^{3}$. The etiology of the condition is largely unknown though it may be associated with an unstable lie, polyhydramnios, multiple gestation, or possibly asymptomatic bacteriuria when group B streptococci are the infective agents ${ }^{4}$.

Eighty percent of PROM is usually followed by spontaneous onset of labour ${ }^{3}$. The time interval between the rupture of membranes \& the onset of labour is defined as the latent period $^{5}$. This may vary from hours to many days. If labour does not occur within 24 hours, it is called prolonged $\mathrm{PROM}^{6}$. Latent period is directly related to the length of gestational age at the time of the rupture. In a study at the University of California in Los Angles, it was found that labour started within 24 hours of PROM in 81 percent of patient carrying babies larger than 2500 grams $^{7}$. The outcome of PROM mainly depends on gestational age, latent period of PROM, associated infection\& neonatal back-up service of the centre where the patient's care is given ${ }^{8}$. Different studies pointed towards the usual occurrence of chorio-amnionitis, ascending infections, dry labour in case of mother \& RDS, neonatal sepsis, birth asphyxia, on the part of neonates as an outcome of term $\mathrm{PROM}^{9}$. In the severe form not only morbidities, it may even result in mortality ${ }^{10}$.

\section{Methodology}

A total number of 100 cases were included in this study having term PROM. Among them 50 patients was managed expectantly and 50 patients undergone active interference.

1. Dr. Bipul Biswas, Registrar (Obstetrics and Gynae), Shaheed Suhrawardy Medical College Hospital, Sher-e-Bangla Nagar, Dhaka.

2. Dr. Israt Jahan, Assistant professor (Obstetrics and Gynae), Shaheed Suhrawardy Medical College Hospital, Sher-e-Bangla Nagar, Dhaka.

3. Dr. Fahmida Sharmin Joty, Medical Officer (Obstetrics and Gynae), Shaheed Suhrawardy Medical College Hospital, Sher-e-Bangla Nagar, Dhaka.

4. Dr. Eva Rani Nandi, Medical Officer (Obstetrics and Gynae), Shaheed Suhrawardy Medical College Hospital, Sher-e-Bangla Nagar, Dhaka.

5. Prof. Farhana Dewan, Professor\& head of dept. of Obstetrics and Gynae, Shaheed Suhrawardy Medical College Hospital, Sher-e-Bangla Nagar, Dhaka.

\section{Correspondence}

Dr. Bipul Biswas(MBBS, FCPS), Registrar (Obstetrics and Gynae), Shaheed Suhrawardy Medical College Hospital, Sher-e-Bangla Nagar, Dhaka Guide: Prof. Farhana Dewan(MBBS, FCPS), Professor\& head of dept. of Obstetrics and Gynae, Shaheed Suhrawardy Medical College Hospital, Sher-e-Bangla Nagar, Dhaka. Dr. Israt Jahan (MBBS, FCPS), Dr. Fahmida Sharmin Joty (MBBS, FCPS), Dr. Eva Rani Nandi(MBBS, FCPS) helped to prepare and write up the article.

Conflict of interest: None

Financial Support: None 
Management options were chosen by the patients and they were selected randomly. Patients presenting with PROM after 37 completed weeks without any contraindication of vaginal delivery were included in the study. Diagnoses of the cases were made by the basis of history, clinical examination and investigations.

Then the patients were managed by dividing into two groups:

i) Expectant management

ii) Active interference-

a) By using misoprostol: when cervix not favourable

b) By using oxytocin : when cervix favourable

Patients coming after 37 completed weeks of pregnancy with a history of passage of gush of fluid per vagina were examined clinically to find out PROM. Investigations include: Pooling test, Nitrazin paper test, Ferning test to confirm PROM \& CBC, Urine R/M/E, Blood grouping and Rh typing, HBsAg, Blood sugar and Ultrasonography of pregnancy profile as routine \& CRP, High vaginal swab for $\mathrm{c} / \mathrm{s}$ and CTG to exclude any adverse situation.

For follow-up, daily CTG, CBC, CRP and Ultrasonography of pregnancy profile and every 3rd day biophysical profile were done. In the meantime patients were given injectable antibiotics-Ampicillin 2 gm i.v 6 hourly and Erythromycin $250 \mathrm{mg}$ i.v 6 hourly for 48 hours \& then Cap. Amoxycillin $250 \mathrm{mg}$ orally 8 hourly and Tab. Erythromycin $333 \mathrm{mg}$ orally 8 hourly for next 7 days. After onset of labour, patients were monitored carefully with maintaining Partograph and maternal \& neonatal outcome were recorded.. Where there was no onset of labour pain within 72 hours of PROM, those patients were excluded from the study. Complications and cases failed to deliver vaginally were also noted in each group. All the relevant information was recorded in a predesigned questionnaire and data were compiled. Then a comparison was made between the two management options to find out better one.

\section{Results:}

Prevalence of PROM in this study was $9.63 \%$ among all Obstetrics cases admitted in ShSMCH during this period of time and term PROM was 8.04\%.

Table- 1: Prevalence of PROM according to gestational age among all Obstetrics patients admitted in hospital $(\mathrm{n}=1879)$

\begin{tabular}{lcc}
\hline Period of gestation & Number of patients & Percentage \\
\hline$>37$ weeks & 151 & $8.04 \%$ \\
$34-36$ weeks & 18 & $0.96 \%$ \\
$31-33$ weeks & 09 & $0.48 \%$ \\
$28-30$ weeks & 03 & $0.16 \%$ \\
Total & 181 & $9.63 \%$ \\
\hline
\end{tabular}

Table- 2: Time interval between PROM and delivery in each group $(n=100)$

\begin{tabular}{l|c|c|c}
\hline $\begin{array}{c}\text { Time interval } \\
\text { (in hours) }\end{array}$ & $\begin{array}{c}\text { Expectant } \\
\text { management }\end{array}$ & $\begin{array}{c}\text { Active } \\
\text { interference }\end{array}$ & p value \\
\hline$<24$ hours & $14(14 \%)$ & $31(31 \%)$ & \\
$24-48$ hours & $25(25 \%)$ & $07(7 \%)$ & \\
$48-72$ hours & $03(3 \%)$ & $02(2 \%)$ & 0.0014 \\
$72-96$ hours & $02(2 \%)$ & $01(1 \%)$ & \\
Failed to deliver & $06(6 \%)$ & $09(9 \%)$ & \\
vaginally & & & \\
\hline
\end{tabular}

This is the most important part showing time interval with onset of PROM and delivery in each group. Overall delivery interval is less in active interference than expectant management ( $\mathrm{p}$ value 0.0014 which is statistically significant). But the rate of failure to deliver vaginally is more in active interference.

The causes of failure to deliver vaginally in each case showed that the rate of caesarean section in active interference is more due to foetal distress and prolonged labour than in expectant management( $p$ value 0.6997 which is statistically not significant).

Table- 3: Causes of LSCS i.e. failure of vaginal delivery in each group $(n=15)$

\begin{tabular}{l|c|c|c}
\hline $\begin{array}{l}\text { Indication of } \\
\text { Caesarean }\end{array}$ & $\begin{array}{c}\text { Expectant } \\
\text { management }\end{array}$ & $\begin{array}{c}\text { Active } \\
\text { interference }\end{array}$ & p value \\
\hline section & $02(13.3 \%)$ & $05(33.3 \%)$ & \\
Foetal distress & $03(20 \%)$ & $02(13.3 \%)$ & 0.6997 \\
Prolonged labour & $01(6.7 \%)$ & $01(6.7 \%)$ & \\
Chorio-amnionitis & & $01(6.7 \%)$ & \\
Cord prolapse & & & \\
\hline
\end{tabular}

Table-4: Maternal outcome in each type of management $(\mathrm{n}=85)$

\begin{tabular}{l|c|c|c}
\hline Name of events & $\begin{array}{c}\text { Expectant } \\
\text { management }\end{array}$ & $\begin{array}{c}\text { Active } \\
\text { interference }\end{array}$ & p value \\
\hline Without any & $37(43.5 \%)$ & $34(40 \%)$ & \\
complications & $2(2.4 \%)$ & $2(2.4 \%)$ & 0.9358 \\
PPH & $2(2.4 \%)$ & $3(3.5 \%)$ & \\
Genital tract & $3(3.5 \%)$ & $2(2.4 \%)$ & \\
injury & & \\
Puerperal pyrexia & $3 \%$ \\
\hline
\end{tabular}

Maternal complications are more in active interference where $p$ value is 0.9358 which is statistically not significant.

Table-5: Foetal outcome in each management group $(n=85)$

\begin{tabular}{l|c|c|c}
\hline $\begin{array}{l}\text { APGAR score at } \\
5 \text { th minute }\end{array}$ & $\begin{array}{c}\text { Expectant } \\
\text { management }\end{array}$ & $\begin{array}{c}\text { Active } \\
\text { interference }\end{array}$ & p value \\
\hline$>7$ & $35(41.2 \%)$ & $32(37.6 \%)$ & \\
$5-7$ & $8(9.4 \%)$ & $7(8.2 \%)$ & 0.8069 \\
$<5$ & $1(1.2 \%)$ & $2(2.4 \%)$ & \\
\hline
\end{tabular}

Regarding foetal outcome APGAR score at 5th minute is better in case of expectant management than that of active interference ( $p$ value 0.8069 which is statistically not significant). 
Table-6: Hospital stays in each group of patients $(n=85)$

\begin{tabular}{l|c|c|c}
\hline Hospital stay & $\begin{array}{c}\text { Expectant } \\
\text { management }\end{array}$ & $\begin{array}{c}\text { Active } \\
\text { interference }\end{array}$ & p value \\
\hline$<1$ day & $7(8.2 \%)$ & $15(17.6 \%)$ & \\
1-2 days & $15(17.6 \%)$ & $19(22.4 \%)$ & 0.0087 \\
$2-3$ days & $19(22.4 \%)$ & $05(5.9 \%)$ & \\
$>3$ days & $03(3.5 \%)$ & $2(2.4 \%)$ & \\
& & & \\
\hline
\end{tabular}

Hospital stay is less in active interference than expectant management ( $\mathrm{p}$ value is 0.0087 which is statistically significant)

\section{Discussion}

PROM is a common Obstetrics problem and most of them are term PROM. This study was performed to find out the incidence, common causes and maternal\& foetal outcome in term PROM. Some patients were managed expectantly (group-1) and some were managed actively by giving induction of labour \& subsequent vaginal delivery without further waiting (group-2). The events of labour were monitored carefully \& outcomes were recorded in a preformed data collection sheet. Then a comparison was made between the two groups regarding pregnancy outcome, maternal\& neonatal morbidities and associated complications.

A lot of national and international publications are there on term PROM. Some similarities and differences were also found in this study with others.

Fifty patient of term PROM without any contra indication of vaginal delivery were selected from the in patient department of ShSMCH. Here the incidence of PROM $(9.63 \%)$ is within the range of international accepted value (2-18\%).

In this study $84 \%$ of group- 1 and $80 \%$ of group- 2 patients had delivered vaginally within 72 hours of onset of labour after term PROM which is near the result of Hannah-et-al (1996) where the rate is $78 \%{ }^{11}$. No maternal or neonatal death occurred in this study population but successful vaginal delivery in group-1(44) was more than in group-2 (41). The complications are almost similar in both the groups and all were managed without any long term morbidities.

APGAR score of the neonates was recorded at 5th minute which showed that group-1 babies are having better APGAR score than group-2. Findings are comparable to the study of Zanzami (2005) where he showed that without any additional risk factor expectant management of PROM at term enhances a patient's chance of normal delivery without an increase in foetal and/or maternal morbidity ${ }^{12}$.

\section{Conclusion}

From this study it can be concluded that both the maternal and neonatal outcome are better in expectant management. Most of the internationally accepted studies also show the same result. But we should have to be rational and each $\&$ every patient should be judged individually so that a better outcome can be ensured. Only then we will be able to avoid an unnecessary surgery in Obstetrics and a better outcome without any complication can be ensured.

\section{References}

1. Arias F. Practical Guide to high risk pregnancy and delivery. 3rd edition, Bangalore; Harcourt Brace and company Asia Pvt. Ltd. 2008.

2. Arias F. Tomich P. Etiology and outcome of low birth weight and preterm infants obstet gynecology 1982;60:277

3. D. C. Dutta, Text Book of Obstetrics 6th edition: 2005

4. Miller JM, Kho Ms Brown HL et al. Clinical Chorioamnionitis is not predicted by an ultrasonic biophysical profile in patient with premature rupture of membranes obstet gynecol 1990: 76: 1051-1054

5. Maxwell LG 1993, Review: Premature rupture of membranes obstet gynecol survey 48; 576-583

6. Bhide AG. Premature rupture of membranes In: Krishan U, Tank Dk, Daftary S. editors, pregnancy at risk. Current concepts 3rd edition, 1997; PP 360

7. Gunn Gc, Mishell Dr. Monton Dg. Premature rupture of membranes. Am J obstet Gynecol 1988; 106-469

8. Moretti M. Sibai BM, Maternal and perinatal outcome of expectant management of premature rupture of membranes in the midtrimester Am J obstet Gynecol 1998; 159-390-96

9. "Stem cells in amniotic fluid show promise", Los Angels Times, Jan 8 2007, retrieved 27 July 2009[1]

(http://www.latimes.com/news/science/la-sci-stemecells8-

jan08,1,2282512.story)

10. "Scientists See Potential In Amniotic Stem Cells", Washington Post, Jan 8 2007, retrieved 27th July2009[3]http://www.wqshington-

post.com/wp-dyn/content/article2007/01/07/AR2007010700674.html)

11. Hannah, M.E., Ohlsson, A., Farine,D., Hewson, S.A., Hodnett, E.D., Myhr, T.L. et. al. (1996). Induction of Labor Compared with Expectant Management for Prelabor Rupture of the Membranes at Term ( TERM PROM study). New England Journal of Medicine, 334(16), 1005-1010. 12. Zanzami, Y. (2005)Prelabor Rupture of membranes at term in low-risk women: induce or wait? Achieves of Gynecology and Obstetrics, Oct. 6: $1-5$.

Table- 1: Prevalence of PROM among all Obstetrics patients $(\mathrm{n}=1879)$ 